DOI 10.18551/rjoas.2019-02.35

\title{
THE EVALUATION OF CHARACTERISTICS OF JAMBI LOCAL RICE (ORYZA SATIVA L.) TOWARD THE AGROECOSYSTEM OF LOWLAND SWAMP FIELDS ON THE VEGETATIVE GROWTH STADIA
}

\author{
Aryunis $^{*}$, Nurdiansyah Fuad \\ Department of Agroecotechnology, Faculty of Agriculture, University of Jambi, Indonesia \\ ${ }^{\star}$ E-mail: aryunis oeddin@yahoo.com
}

\begin{abstract}
The evaluation of characteristics of Jambi local rice (Oryza sativa L.) toward the agroecosystem of lowland swamp fields on the vegetative growth stadia is aimed to achieve the variety of Jambi local rice that is adaptive to the extreme condition of swamp on rainfed lowlands so that the erratic rainfall due to the climate change can be overcome and as an enrichment of germplasm sources for reparation and manipulation of new superior varieties that can cope with the climate changes and improve the rice production. This study was conducted in 2018 in a lowland swamp belongs to the farmers of Lubuk Ruso Village, Subdistrict of Pemayung, Batanghari District, Province of Jambi. The test materials are varieties of local rice from Jambi, as a result of exploration in 2004, 2009, 2013, and 2018 in the province of Jambi. The screening of the adaptive lowland swamp was conducted on the nursery stage until the growth of sprouts at its maximum in accordance with the soil moisture content related to the rainfall, as many as 24 varieties of Jambi local rice. This study is selection research of Jambi local rice toward the agroecosystem of lowland swamp fields on the vegetative growth stadia. The observation is conducted on the morphology characteristics that are adaptive to the lowland swamp. The findings show the difference in morphological characteristics of adaptation abilities from the varieties of Jambi local rice evaluated on the lowland swamp. Of all 24 varieties of adaptive local rice, there are 19 varieties which have a character of short-stemmed sprout and 5 varieties which have a character of medium-stemmed sprout.
\end{abstract}

\section{KEY WORDS}

Jambi local rice, landraces, adaptation, swamp, vegetative stadia.

About $30 \%$ of global rice (Oryza sativa) is produced in an agriculture field which is located on a low elevation which irrigation is sourced from the rainfall (Bailey-Serres et al., 2010). The rainfed rice fields reduce the soil moisture, water pollution, and soil salinization, which is often affiliated with the controlled irrigation system. However, the rainfed rice fields are prone to flood and drought due to inadequate water management. Therefore, puddles, drought, and other substantial events will lower the rice productivity, as well as sequential events (submersion followed by drought and vice versa) which are the primary obstacles in the production of rice in rainfed rice fields on lowlands.

Generally, rice is sensitive to dryness because it requires a certain amount of water, yet the variety of gogo rice and rainfed lowland rice have more tolerance for dryness. The molecular genetic analysis detects a number of locus characteristics related to the components which influence the tolerance on dryness, including the production of seeds, shoot and root morphology, and the status of leaf water (Lanceras et al, 2004;. Yue et al, 2006;. Venuprasad et al, 2009). The dryness and submersion are two primary abiotic obstacles that are very influential to the plant's growth and productivity. The global climate change that affects the occurrence of uncertain rainfall, prolonged drought, and excessive rainfall makes it necessary to find the varieties that are resistant to those two circumstances. One of the applicable attempts is to seek for local, adaptive varieties to both the obstacles of submersion and dryness because the varieties of local rice have strength wherein they have adapted to the environmental situation from generation to generation for years. However, the 
strength of local rice varieties is primary on submersion and for dryness has not been much explored.

The province of Jambi has a wide and numerous rainfed fields with the varieties of local rice. The location of paddy fields in Jambi can be found alongside the flow of Batanghari river, therefore it is often flooded (submerged) and drought due to the extreme climate change. So far, it has not been explored the varieties of local rice from Jambi that are resistant to the submersion and dryness. The rice's productivity will be lowered if the climate change happens extremely during planting, yet, on the other side, there are varieties that have good productivity in such environment.

Exploration is an activity to seek, collect, and examine types of varieties in certain locations. Aryunis et al., (2004) had explored and identified the quality and taste of local race in tidal lands in Tanjung Jabung Barat District of Jambi Province. The research found 42 varieties of local tidal land rice and 6 varieties of field rice. Aryunis et al., (2009) continued the exploration and identification of agronomic characteristics of local rice in three districts in the Province of Jambi, namely Tanjung Jabung Timur, Bungo, and Kerinci districts based on agroecology including paddy, rainfed, field, tides, and swamps. From the exploration, acquired 90 varieties of local rice, 25 are rice fields. The varieties of rice on average had longevity (6 months). The following research Aryunis et al., (2011) had done a genetic mapping on 30 local field rice varieties. Yet, the morphological characteristic of vegetative growth of accession varieties of Jambi local rice to lowland swamps has not been explored.

\section{METHODS OF RESEARCH}

The data used in this study are the varieties of local rice from Jambi reported through the findings of explorative research by Aryunis et al., (2004 and 2009) and the result of exploration by Aryunis (2013 and 2018) on the agroecosystem of wetlands and dry lands in the Province of Jambi as many as 24 varieties, urea fertilizer, $\mathrm{KCl}$, and SP36.

The instruments used in this study include Saprodi, Alsintan in accordance with the local recommendation. The planting place of plastic tubs sized $50 \mathrm{~cm} \times 25 \mathrm{~cm} \times 5 \mathrm{~cm}$, petri dish cups, aluminum cups, and paper straws.

This study was conducted in 2018 on the lowland swamp that belongs to the farmers of Lubuk Ruso Village, Pemayung Subdistrict, Batanghari District Province of Jambi. It was conducted from May to October 2018.

The local rice from Jambi, which is the result of exploration, is evaluated to select the specific morphological characters from the accession of local Jambi rice varieties that are adaptive to the agroecosystem of rainfed lowland swamps. The evaluation was conducted on the vegetative growth stadia. The findings are presented in a form of a descriptive table.

This research will be conducted in one phase, which is Evaluation (screening). The Evaluation of the Potential Results and Characteristics of Jambi Local Rice that are adaptive to the Agroecosystem of Rainfed Lowland Swamps toward 105 accessions of Jambi local rice varieties. This study is based on the ability of high production and specific agronomic characteristics. The results of the study are expected to find the accession of the selected local rice varieties that are adaptive to the agroecosystem of rainfed lowland swamp. The cultivation technique is implemented in accordance with the standard operational procedure of in situ rice cultivation on the fields of rainfed lowland swamp.

An observation was conducted to the vegetative growth characteristic, reproductive growth, result components, results, contents of organic N, P, K, C, and EC soil, and the climate data throughout the research period.

In order to acknowledge the characteristics of adaptation ability on the lowland swamp toward the morphological characters, descriptive analysis is used and presented in a form of a descriptive table.

An observation is conducted on the plants' height, number of sprouts, angle of stems, diameter of stems, color of stems, and color of leaf neck. 


\section{RESULTS AND DISCUSSION}

The findings show that there are diverse abilities of adaptation on Jambi local rice varieties that are tested on lowland swamps regarding the morphological characters (Table 1).

Table 1 - The plants' height, number of sprouts, angle of stems, diameter of stems, color of stems, and color of leaf neck.of Jambi local rice varieties that are adaptive to the agroecosystem of rainfed lowland swamp

\begin{tabular}{|l|l|l|l|l|l|l|l|}
\hline No.Urut & No.Accession & Varieties Names & $\begin{array}{l}\text { Plant } \\
\text { height }\end{array}$ & $\begin{array}{l}\text { Number of } \\
\text { sprouts }\end{array}$ & $\begin{array}{l}\text { Stem } \\
\text { angle }\end{array}$ & $\begin{array}{l}\text { Stem } \\
\text { color }\end{array}$ & $\begin{array}{l}\text { Leaf neck } \\
\text { color }\end{array}$ \\
\hline 1 & 89 & Gadis Jambi & 94.09 & 31.81 & Medium & Green & Green \\
\hline 2 & 90 & Bujang Berinai & 79.00 & 40.00 & Closed & Green & Green \\
\hline 3 & $90 \mathrm{~A}$ & Karya Rendah & 86.72 & 44.28 & Closed & Green & Green \\
\hline 4 & 52 & Payo & 92.33 & 26.33 & Closed & Green & Green \\
\hline 5 & $46 \mathrm{~A}$ & $\begin{array}{l}\text { Beras Merah Putih } \\
\text { Kecil (white rice) }\end{array}$ & 84.67 & 27.67 & Medium & Green & Green \\
\hline 6 & $46 \mathrm{~B}$ & $\begin{array}{l}\text { Beras Merah Putih } \\
\text { Besar) (red rice) }\end{array}$ & 89.67 & 28.67 & Open & Green & Green \\
\hline 7 & $46 \mathrm{C}$ & Beras Merah & 97.67 & 31.67 & Medium & Green & Green \\
\hline 8 & 91 & Pandan Wangi & 74.33 & 32.67 & Closed & Green & Green \\
\hline 9 & 92 & $\begin{array}{l}\text { Padi Ungul } \\
\text { Pemerintah }\end{array}$ & 93.17 & 35.67 & Closed & Green & Green \\
\hline 10 & 93 & Telur Bujuk & 123.00 & 36.00 & Medium & Purple & Purple \\
\hline 11 & 95 & Padi Bawang & 105.33 & 44.67 & Closed & Green & Green \\
\hline 12 & 96 & Pandan Wangi & 103.83 & 34.67 & Closed & Green & Green \\
\hline 13 & 97 & Raden Kuning & 100.67 & 29.11 & Closed & Green & Green \\
\hline 14 & 98 & Raden Kuning bulat & 111.00 & 24.00 & Open & Green & Green \\
\hline 15 & 99 & $\begin{array}{l}\text { Raden Kuning } \\
\text { Panjang }\end{array}$ & 93.33 & 31.33 & Medium & Green & Green \\
\hline 16 & 101 & Rimbun Daun & 71.67 & 40.00 & Closed & Purple & Purple \\
\hline 17 & 103 & Gadis Jambi & 78.67 & 24.00 & Closed & Green & Green \\
\hline 18 & 104 & Sempol & 95.33 & 28.33 & Medium & Green & Green \\
\hline 19 & 105 & Kuning Betung & 91.17 & 30.50 & Closed & Green & Green \\
\hline 20 & 106 & Karya Rendah & 46.58 & 29.33 & Closed & Purple & Purple \\
\hline 21 & 107 & Padi Cino & 95.44 & 30.11 & Medium & Green & Green \\
\hline 22 & 108 & Karya Tinggi & 89.56 & 35.17 & Medium & Green & Green \\
\hline 23 & 109 & Kuning Mas & 89.33 & 25.67 & Closed & Green & Green \\
\hline 24 & 110 & Kuning Kelinci & 92.67 & 39.83 & Open & Green & Green \\
\hline
\end{tabular}

The findings show that the 24 varieties of Jambi local rice have a good and adaptive vegetative growth characteristic on the agroecosystem of rainfed lowland swamp (Table 1). According to the Evaluation of Rice Characteristics by IBPGR IRRI (1980) and Chang and Berdenas (1965), Jambi local rice varieties that are adaptive to swap lowlands and have characters of short stem and multiple sprouts include the varieties of Gadis Jambi, Bujang Berinai, Karya Rendah, Payo, Beras Merah Putih Kecil (white rice), Beras Merah Putih Besar) (red rice), Beras Merah, Pandan Wangi, Padi Unggul Pemerintah, Raden Kuning Panjang, Rimbun Daun, Gadis Jambi, Sempol, Kuning Betung, Karya Rendah, Padi Cino, Karya Tinggi, Kuning Mas and Kuning Kelinci. The varieties that have characters of mediumlong stem and multiple sprouts include Telur Bujuk, Padi Bawang, Pandan Wangi, Raden Kuning, and Raden Kuning (Table 1). The findings indicate that as many as 24 varieties of Jambi local rice, which were evaluated for its adaptation on lowland swamps, there is a variety of characteristics on the plant's height and there is no variety of characteristics on the number of sprouts. In other words, this study indicates that the varieties of local rice that are adaptive to lowland swamps are rice that have a characteristic of height short to medium and have a characteristic of multiple sprouts (Figure 1 and 2). 

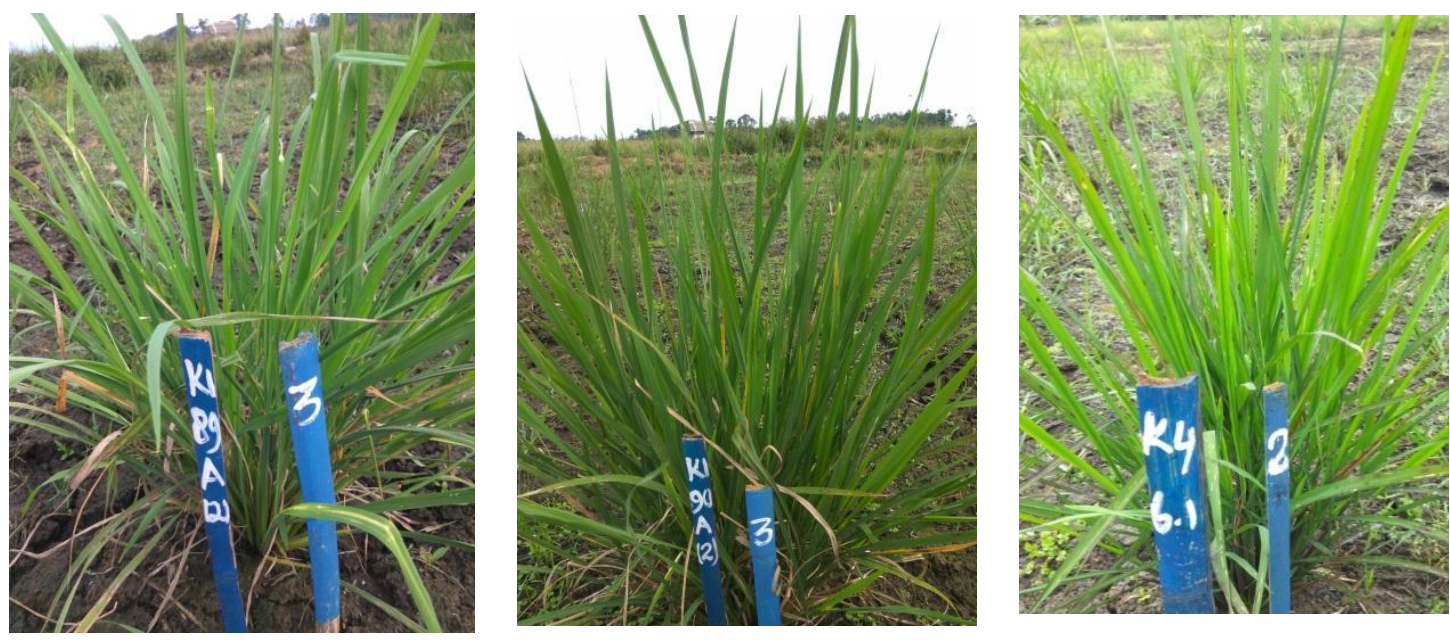

Figure 1 - The characteristics of Jambi local rice that have short stems and multiple sprouts
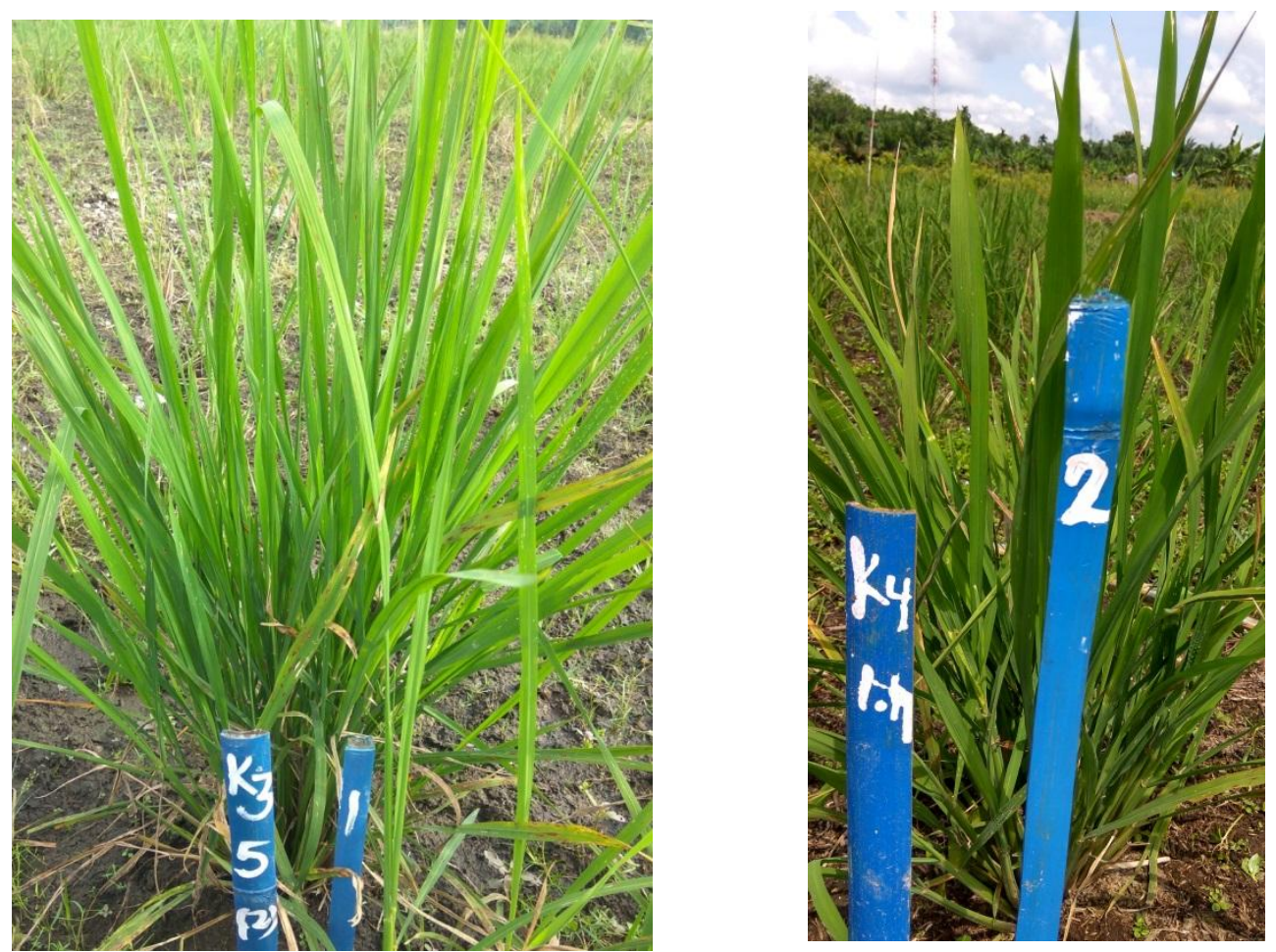

Figure 2 - Characteristics of Jambi local rice that have medium-long stem and multiple sprouts

\section{CONCLUSION}

The 24 varieties of Jambi local rice, that are evaluated on the agroecosystem of rainfed lowland swamps, have a good vegetative growth adaptation with a characteristic of short stems and multiple sprouts of 19 varieties and a medium-long stem with multiple sprouts of 5 varieties.

\section{ACKNOWLEDGMENTS}

Thank you to the Head of Research and Services Institution, to the Academia of Universitas Jambi who provided financial support DIPA PNBP LP2M Universitas Jambi, and Mr. Samirun who provided land and assistance regarding the research implementation. 


\section{REFERENCES}

1. Aryunis, Esrita \& F. Tafzi. 2004. Eksplorasi Padi Lokal Pasang Surut dengan Rasa Nasi Enak di Kabupaten Tanjung Jabung Barat Provinsi Jambi. Research Report. Universitas Jambi.

2. Aryunis \& Tafzi, F. 2009. Eksplorasi and identifikasi padi lokal asal Jambi berdasarkan Agroekologi. Research Report. Universitas Jambi

3. Aryunis \& Tafzi, F. 2011. Identifikasi karakteristik beras, mutu tanak nasi danpemetaan genetik padi ladang lokal asal jambi untuk pelestarianplasmanutfah and perakitan varietas padi ladang berumur genjah. Research Report. Universitas Jambi

4. Bailey-Serres J, Voesenek LACJ. 2010. Life in the balance: a signaling network controlling survival of flooding. Curr Opin Plant Biol 13:489-494

5. Chang, T.T. \& Berdenas, E.A. 1965. The morfologi and varietal characteristic of the rice plant. IRRI Tech. Bull (4).

6. IBPGR-IRR1. 1980. Descriptors for rice Oryza sativaL. IRRI, Manila, Philippines.

7. Lanceras, J.C., 2004. Quantitative trait loci associated with drought tolerance at reproductive stage in rice. Plant Physiol. 135: 384-399.

8. Venuprasad, R., Dalid, C.O., Del Valle, M., Zhao, D., Espiritu, M., Sta Cruz, M.T., Amante, M., Kumar, A., and Atlin, G.N. 2009. Identification and characterization of largeeffect quantitative trait loci for grain yield under lowland drought stress in rice using bulksegregant analysis. Theor. Appl. Genet. 120: 177-190.

9. Yue, B., Xue, W., Xiong, L., Yu, X., Luo, L., Cui, K., Jin, D., Xing, Y., and Zhang, Q. 2006. Genetic basis of drought resistance at reproductive stage in rice: Separation of drought tolerance from drought avoidance. Genetics 172: 1213-1228. 